Key Words:

Carbonate Distribution

Coefficient $\left(K_{d}\right)$, Desorption, Anion Exchange, Sediments, Concrete

Retention:

Permanent

\title{
CARBON-14 GEOCHEMISTRY AT THE SAVANNAH RIVER SITE
}

\author{
Kimberly A. Roberts \\ Daniel I. Kaplan
}

$5 / 10 / 2013$

Savannah River National Laboratory

Savannah River Nuclear Solutions

Savannah River Site

Aiken, SC 29808 


\section{DISCLAIMER}

This report was prepared for the United States Department of Energy under Contract No. DE-AC09-08SR22470 and is an account of work performed under that contract. Neither the United States Department of Energy, nor SRNS, nor any of their employees makes any warranty, expressed or implied, or assumes any legal liability or responsibility for accuracy, completeness, or usefulness, of any information, apparatus, or product or process disclosed herein or represents that its use will not infringe privately owned rights. Reference herein to any specific commercial product, process, or service by trade name, trademark, name, manufacturer or otherwise does not necessarily constitute or imply endorsement, recommendation, or favoring of same by Savannah River Nuclear Solutions or by the United States Government or any agency thereof. The views and opinions of the authors expressed herein do not necessarily state or reflect those of the United States Government or any agency thereof.

Printed in the United States of America

Prepared For

U.S. Department of Energy 
Key Words:

Carbonate Distribution

Coefficient $\left(K_{d}\right)$, Desorption, Anion Exchange, Sediments, Concrete

Retention:

Permanent

\title{
CARBON-14 GEOCHEMISTRY AT SAVANNAH RIVER SITE
}

\author{
Kimberly A. Roberts \\ Daniel I. Kaplan
}

$5 / 10 / 2013$

Savannah River National Laboratory

Savannah River Nuclear Solutions

Savannah River Site

Aiken, SC 29808

Prepared for the U.S. Department of Energy Under

Contract Number DE-AC09-08SR22470

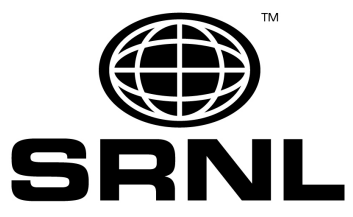




\section{REVIEWS AND APPROVALS}

Kimberly A. Roberts, Co-author, Radiological Performance Assessment

Date

Daniel I. Kaplan, Co-author, Environmental Sciences

Date

Morgana T. Whiteside, Peer Reviewer, Analytical Technical Support

Date

David A. Crowley, Manager, Radiological Performance Assessment

Date

R. S. Aylward, Manager, Environmental Management

Date 


\section{TABLE OF CONTENTS}

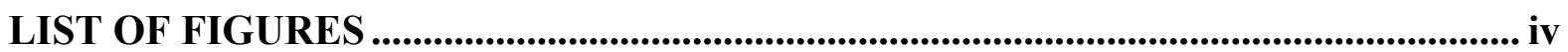

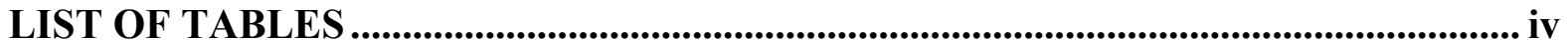

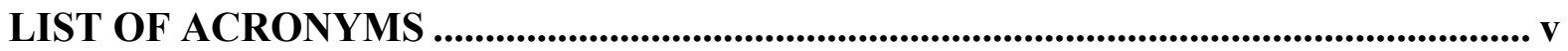

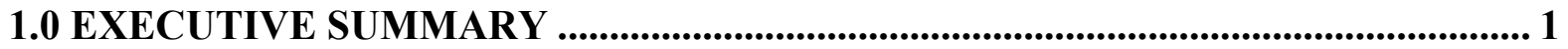

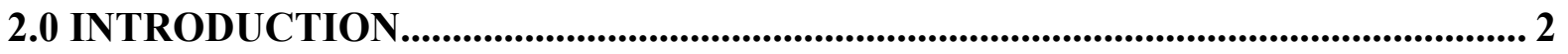

3.0 MATERIALS AND METHODS ............................................................................. 4

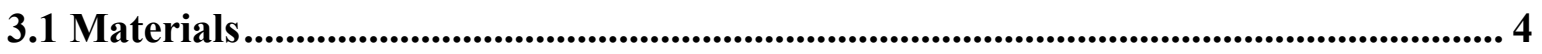

3.2 Methods for the (Ad)Sorption Experiment ..................................................................... 4

3.3 Methods for the desorption Experiment ..................................................................... 5

4.0 RESULTS AND DISCUSSION OF GEOCHEMISTRY EXPERIMENTS................ 6

4.1 (Ad)sorption Experiment ........................................................................................6 6

4.2 Desorption Experiment ................................................................................................. 10

5.0 CONCLUSIONS ........................................................................................................ 12

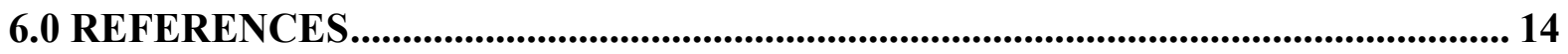

APPENDIX A. CARBON-14 RAW DATA AND RESEARCH AND DEVELOPMENT

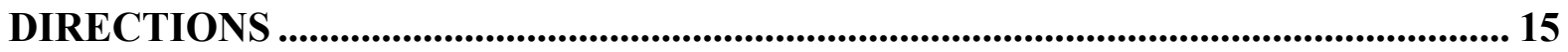




\section{LIST OF FIGURES}

Figure 1. Bjerrum plot of carbonate species at $\mathrm{CO}_{2}=10^{-2}$ and $\mathrm{T}=25^{\circ} \mathrm{C}$ (from Drever, 1997) 2 Figure 2. Percent of ${ }^{14} \mathrm{C}$, added as $\mathrm{Na}_{2}{ }^{14} \mathrm{CO}_{3}$, sorbed to clay particles as a function of time with a particle concentration of $83.3 \mathrm{mg} / \mathrm{L}$. Each data point represents the average of replicate measurements and the error bar is propagated counting uncertainty.

Figure 3. Percent of ${ }^{14} \mathrm{C}$, added as $\mathrm{Na}_{2}{ }^{14} \mathrm{CO}_{3}$, sorbed to sand particles as a function of time with a particle concentration of $83.3 \mathrm{mg} / \mathrm{L}$. Each data point represents the average of replicate measurements and the error bar is propagated counting uncertainty.

Figure 4. Percent of ${ }^{14} \mathrm{C}$, added as $\mathrm{Na}_{2}{ }^{14} \mathrm{CO}_{3}$, sorbed to 36 -year-old concrete as a function of time with a particle concentration of $8.3 \mathrm{mg} / \mathrm{L}$. Each data point represents the average of replicate measurements and the error bar is propagated counting uncertainty.

Figure 5. Percent of ${ }^{14} \mathrm{C}$, added as $\mathrm{Na}_{2}{ }^{14} \mathrm{CO}_{3}$, sorbed to reducing grout particles as a function of time with a particle concentration of $8.3 \mathrm{mg} / \mathrm{L}$. Each data point represents the average of replicate measurements and the error bar is the propagated counting uncertainty........ 9

Figure 6. Activity of ${ }^{14} \mathrm{C}$-carbonate in solution after desorption experiment in $0.01 \mathrm{M}$ anion (nitrate, carbonate or phosphate) solutions to assess competitive replacement. 10

Figure 7. Percent of anion sorbed by the clayey sediment and the 36-year-old concrete during the desorption experiment. About $0.01 \mathrm{M}$ anion solution was added of each anion. The negative phosphate values indicate that some phosphate was desorbed from the solid phases upon adding phosphate to the suspensions.

Figure 8. Comparison of Apparent $\mathrm{K}_{\mathrm{d}}$ values for SRS Sandy and Clayey sediments versus recommended value for use in PA analyses for $\mathrm{C}-14$.

\section{LIST OF TABLES}

Table 1. $\mathrm{K}_{\mathrm{d}}(\mathrm{mL} / \mathrm{g})$ data for ${ }^{14} \mathrm{C}$ on different solids as a function of time (from Allard et. al, 1981) where $\mathrm{h}=$ hour, $\mathrm{d}=$ day, $\mathrm{w}=$ week and $\mathrm{m}=$ month. ........................................ 3

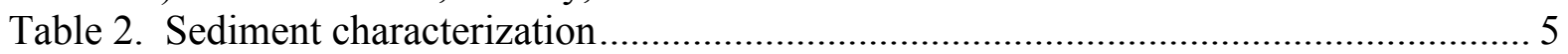

Table 3. Characterization of the cementitious materials used in studies ................................ 5

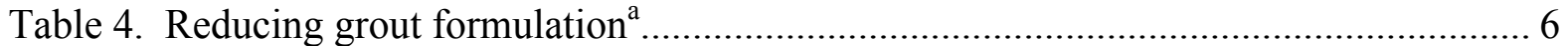

Table 5. $\mathrm{K}_{\mathrm{d}}$ data for ${ }^{14} \mathrm{C}$-carbonate $(\mathrm{mL} / \mathrm{g})$ on different solids as a function of time............... 9 


\section{LIST OF ACRONYMS}

$\begin{aligned} \text { cpm } & \text { Counts per minute } \\ \mathrm{K}_{\mathrm{d}} & \text { Distribution Coefficient } \\ \text { SRS } & \text { Savannah River Site } \\ \text { SRNL } & \text { Savannah River National Laboratory } \\ \text { SRNS } & \text { Savannah River Nuclear Solutions } \\ \text { OBG } & \text { Old Burial Ground } \\ \text { MWMF } & \text { Mixed Waste Management Facility } \\ \text { LLRDWF } & \text { Low-level Radioactive Disposal Waste Facility } \\ \text { PA } & \text { Performance Assessment }\end{aligned}$




\subsection{EXECUTIVE SUMMARY}

Carbon-14 is among the key radionuclides driving risk at the E-Area Low-Level Waste Disposal Facility on the Savannah River Site (SRS). Much of this calculated risk is believed to be the result of having to make conservative assumptions in risk calculations because of the lack of sitespecific data. The original geochemical data package (Kaplan 2006) recommended that performance assessments and composite analyses for the SRS assume that ${ }^{14} \mathrm{C}$ did not sorbed to sediments or cementitious materials, i.e., that C-14 $\mathrm{K}_{\mathrm{d}}$ value (solid:liquid concentration ratio) be set to $0 \mathrm{~mL} / \mathrm{g}$ (Kaplan 2006). This recommendation was based primarily on the fact that no sitespecific experimental work was available and the assumption that the interaction of anionic ${ }^{14} \mathrm{C}$ (as $\mathrm{CO}_{2}{ }^{2-}$ ) with similarly charged sediments or cementitious materials would be minimal. When used in reactive transport equations, the $0 \mathrm{~mL} / \mathrm{g} \mathrm{K}$ value results in ${ }^{14} \mathrm{C}$ not interacting with the solid phase and moving quickly through the porous media at the same rate as water. The objective of this study was to quantify and understand how aqueous ${ }^{14} \mathrm{C}$, as dissolved carbonate, sorbs to and desorbs from SRS sediments and cementitious materials.

Laboratory studies measuring the sorption of ${ }^{14} \mathrm{C}$, added as a carbonate, showed unequivocally that ${ }^{14} \mathrm{C}$-carbonate $\mathrm{K}_{\mathrm{d}}$ values were not equal to $0 \mathrm{~mL} / \mathrm{g}$ for any of the solid phases tested, but they required several months to come to steady state. After six months of contact, the apparent $\mathrm{K}_{\mathrm{d}}$ values for a clayey sediment was $3,000 \mathrm{~mL} / \mathrm{g}$, for a sandy sediment was $10 \mathrm{~mL} / \mathrm{g}$, for a 36 -yearold concrete was $30,000 \mathrm{~mL} / \mathrm{g}$, and for a reducing grout was $40 \mathrm{~mL} / \mathrm{g}$. Furthermore, it was demonstrated that (ad)sorption rates were appreciably faster than desorption rates, indicating that a kinetic sorption model, as opposed to the steady-state $\mathrm{K}_{\mathrm{d}}$ model, may be a more accurate description of the ${ }^{14} \mathrm{C}$-carbonate sorption process. A second study demonstrated that the ${ }^{14} \mathrm{C}$ carbonate sorbed very strongly onto the various materials and could not be desorbed by anion exchanged with high concentrations of carbonate or nitrate. High phosphate concentrations were able to desorb ${ }^{14} \mathrm{C}$-carbonate from the 36 -year-old concrete sample, but not the clayey sediment sample. Together these geochemistry studies support the use of non-zero $\mathrm{K}_{\mathrm{d}}$ values in risk calculations on the SRS.

For performance assessment (PA) calculations, ${ }^{14} \mathrm{C}$ would be moving with the groundwater, remaining in contact with sediment for days, not months. Therefore for purposes of SRS risk calculations, it is appropriate to select sorption values after a couple days of contact, departing from the traditional definition that states $K_{d}$ values reflect the system under steady state conditions. Such an "apparent $\mathrm{K}_{\mathrm{d}}$ value," would be expected to provide a better (and more conservative) estimate of what to expect under SRS PA conditions. Based on these results, recommended apparent $K_{d}$ values for use in the PA are $1 \mathrm{~mL} / \mathrm{g}$ for sandy sediments and $30 \mathrm{~mL} / \mathrm{g}$ for clayey sediments.

This document is a revision of a document issued on 12/09/2008 (Roberts and Kaplan 2008). This revision includes recommended "apparent $\mathrm{K}_{\mathrm{d}}$ values" based on contact times of a couple days (as well as some editorial changes). 


\subsection{INTRODUCTION}

Carbon-14 ( $\mathrm{t}_{1 / 2}=5730$ years) was produced at the Savannah River Site (SRS) from 1954 to 1989 by the ${ }^{17} \mathrm{O}(\mathrm{n}, \alpha){ }^{14} \mathrm{C}$ reaction. Areas on the SRS at which ${ }^{14} \mathrm{C}$ was found are the Old Burial Ground (OBG), the Mixed Waste Management Facility (MWMF), and the E-Area Low-level Radioactive Waste Disposal Facility (LLRWDF). Estimates of the total ${ }^{14} \mathrm{C}$ released or placed in the ground as low-level waste are as much as $6600 \mathrm{Ci}$ (McIntyre, 1988; Hiergesell et al., 2008).

Given the large quantity of ${ }^{14} \mathrm{C}$ at the $\mathrm{SRS}$, it is important to develop an accurate conceptual biogeochemical model as well as to quantify the important processes influencing ${ }^{14} \mathrm{C}$ fate and transport in the environment. A majority of the ${ }^{14} \mathrm{C}$ in the LLRWDF is believed to be associated with resins, existing as loose entities or contained within stainless steel containment vessels (from the K- and L- Disassembly Basin Facility), used to maintain low dissolved salts and radionuclide concentrations in spent fuel basin waters.

Carbonate chemistry is complex because under field conditions it can exist as a solid, liquid, and/or gas and its speciation is highly $\mathrm{pH}$ dependent. Figure 1 shows carbon speciation as a function of $\mathrm{pH}$ where $\mathrm{H}_{2} \mathrm{CO}_{3}{ }^{0}$ and $\mathrm{HCO}_{3}{ }^{-}$dominate under most groundwater $\mathrm{pH}$ conditions, and $\mathrm{CO}_{3}{ }^{2-}$ is the primary species only under very alkaline conditions, $\mathrm{pH}$ values $>10$, such as cementitious environments. It is anticipated that there will be negligible amounts of ${ }^{14} \mathrm{C}$ existing as organic moieties in the aqueous phase of the low-level waste environment because much of the ${ }^{14} \mathrm{C}$ originates from inorganic carbonate adsorbed to anion exchange resins from the $\mathrm{K}$ and $\mathrm{L}$ Disassembly Basin Facility and there is relatively little organic carbon, such as fulvic and humic acids, in the SRS subsurface groundwater.

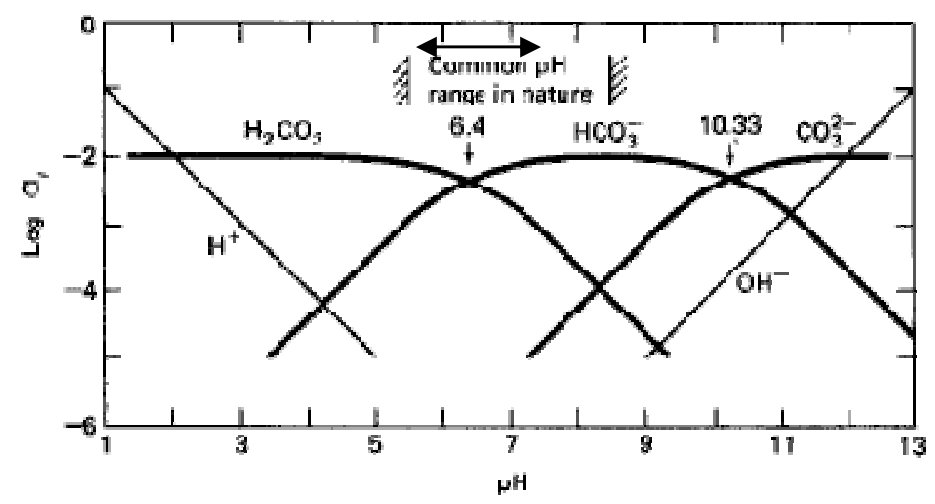

Figure 1. Bjerrum plot of carbonate species at $\mathrm{CO}_{2}=10^{-2}$ and $\mathrm{T}=25^{\circ} \mathrm{C}$ (from Drever, 1997). The expected pH range for solution in contact with cementitious materials is pH 10 to 13 .

Currently, SRS models use an equilibrium isotherm based $\mathrm{K}_{\mathrm{d}}$ (sediment-water partitioning coefficient) value of $0 \mathrm{~mL} / \mathrm{g}$ indicating that there is no sorption of or interaction between ${ }^{14} \mathrm{C}$ and subsurface soils (Kaplan 2006). Here local sorption and desorption rates are assumed to be 
infinite thus resulting in local phasic equilibrium at all time scales. This is a conservative approach and one that is used because studies using site-specific materials have not been undertaken to measure more accurate values. This low $\mathrm{K}_{\mathrm{d}}$ value is based on the assumption that ${ }^{14} \mathrm{C}$ exists as a carbonate, thereby possessing a negative charge and being repulsed from SRS sediments and cementitious materials, which also have negative charges. Chemical behavior of ${ }^{14} \mathrm{C}$ would depend greatly on the disposal location and the geochemistry of its immediate surroundings, i.e., background sediment, stainless steel, and cementitious materials. In turn, these varying background materials would influence the $\mathrm{pH}$ and thus the dominant carbonate species.

Much is known about carbonate chemistry in alkaline environments, but much less is known about it under slightly acidic conditions, as exist in natural SRS sediments (Reeder 1983). This is due to carbonate minerals existing only in alkaline conditions. The sorptive behavior of ${ }^{14} \mathrm{C}$, primarily via adsorption, is generally of much less widespread interest than understanding natural stable ${ }^{12} \mathrm{C}$-carbonates. McIntyre (1988) measured ${ }^{14} \mathrm{C}$, as a carbonate, transient $\mathrm{K}_{\mathrm{d}}$ values on SRS sediment of $2 \mathrm{~mL} / \mathrm{g}$ after 7 hours and $55 \mathrm{~mL} / \mathrm{g}$ after 72 hours. Table 1 is a compilation of ${ }^{14} \mathrm{C}$ sorption data for different solids by Allard et al. (1981). The large $\mathrm{K}_{\mathrm{d}}$ values after 1 week for the concrete and cement paste likely represent sorption via coprecipitation as a solid carbonate phase.

Table 1. $K_{d}(\mathrm{~mL} / \mathrm{g})$ data for ${ }^{14} \mathrm{C}$ on different solids as a function of time (from Allard et. al, 1981) where $h=$ hour, $d=$ day, $w=$ week and $m=$ month.

\begin{tabular}{l|llllllll}
\hline Solid & $\mathbf{0 . 5 h}$ & $\mathbf{2 h}$ & $\mathbf{6 h}$ & $\mathbf{2 4 h}$ & $\mathbf{3 d}$ & $\mathbf{1 w}$ & $\mathbf{5 w}$ & $\mathbf{6 m}$ \\
\hline Bentonite/quartz & & & & & 2.8 & 8.6 & 7.6 & 7.8 \\
Sandy moraine & 1 & 0.2 & 0.7 & 0.5 & 0.8 & 1.1 & 2.6 & 2.2 \\
Clayish moraine & 1.9 & 0.7 & 1.3 & 1.4 & 1.3 & 2.0 & 3.0 & 2.3 \\
Calcite & 1.0 & 1.0 & 1.5 & 1.7 & 3.7 & 3.5 & 9.0 & 83 \\
Concrete & & & & & 5.3 & 1600 & $>10^{4}$ & \\
\hline Cement paste & & & & & 7.4 & 1600 & $>10^{4}$ & \\
\hline
\end{tabular}

The process of desorption of ${ }^{14} \mathrm{C}$ is also of interest because a hysteresis effect is commonly reported for radionuclides that sorb via precipitation or coprecipitation (Krupka et al. 1999). Hysteresis is the process when (ad)sorption and desorption rates of solutes to solids are markedly different. The $\mathrm{K}_{\mathrm{d}}$ construct assumes (ad)sorption and desorption rates are identical and large. There are many examples in the literature of when desorption is slower than (ad)sorption rates, especially when precipitation or coprecipitation of the solute has occurred.

Kaplan and Coffey (2002) found that the desorption $\mathrm{K}_{\mathrm{d}}$ for ${ }^{14} \mathrm{C}$ from spent resin was $240 \mathrm{~mL} / \mathrm{g}$ in acid-rain leachate (lower $\mathrm{pH}$ ) and $140 \mathrm{~mL} / \mathrm{g}$ in cement leachate (higher $\mathrm{pH}$ ). This data suggests that not only is the solid phase important (in this case resin) but also the $\mathrm{pH}$ of the system in understanding $\mathrm{K}_{\mathrm{d}}$ values. 
The existence of non-zero $K_{d}$ values in the literature provides an impetus for measuring SRS site-specific values. Thus, the objectives of this study were to:

1. measure ${ }^{14} \mathrm{CO}_{3}{ }^{2-} / \mathrm{H}^{14} \mathrm{CO}_{3}{ }^{-} / \mathrm{H}_{2} \mathrm{CO}_{3}{ }^{0}$ (henceforth referred to as carbonate) sorption parameters, $\mathrm{K}_{\mathrm{d}}$ or solubility values, on SRS sediments and cementitious materials applicable for use in SRS performance assessments and composite analyses;

2. determine the sorption kinetics of ${ }^{14} \mathrm{C}$-carbonate onto these surfaces to evaluate whether the sorption reaction is kinetically hindered, compromising the application of the $\mathrm{K}_{\mathrm{d}}$ construct in reactive transport modeling; and

3. determine how strongly ${ }^{14} \mathrm{C}$-carbonate is retained by geo-sorbents by adding varying concentrations of competing anions. The competitive anions will have varying valences and ionic radii.

\subsection{MATERIALS AND METHODS}

\subsection{MATERIALS}

Detailed experimental procedures are documented in Appendix A. Briefly, $1 \mathrm{~g}$ of sediment or 0.1 $\mathrm{g}$ of cementitious material was combined with $10 \mathrm{~mL}$ of SRS groundwater (collected from near PAR Pond). Characterization of the two sediments is presented in Table 2. There were two types of cementitious materials. One was an aged cementitious material recovered from the base pad of a non-rad tank located in P-Area of the SRS that was poured in 1972 and had been exposed to the natural elements since then. An internal portion of the core, a portion that was not in contact with the air or the underlying soil, was taken for use in this study. The sample was crushed, passed through a mill, and then the $<1-\mathrm{mm}$ fraction was used in this study. The second cementitious sample was a reducing grout, similar to those that may be used in tank closure. This sample was prepared by Christine Langton (SRNL), permitted to cure for 1 month, crushed, milled, and then passed through a $1-\mathrm{mm}$ sieve. The $<1-\mathrm{mm}$ sieved fraction was used in these tests. Some properties of these materials are presented in Table 3 and the formulation of the reducing grout is presented in Table 4.

\subsection{METHODS FOR THE (AD)SORPTION EXPERIMENT}

A ${ }^{14} \mathrm{C}$-carbonate spike solution $\left({ }^{14} \mathrm{C}\right.$-carbonate as sodium carbonate in $\left.0.001 \mathrm{M} \mathrm{NaOH}\right)$ was added to create a suspension with a final specific activity of $0.0017 \mu \mathrm{Ci} / \mathrm{L}{ }^{14} \mathrm{C}$. The resulting suspension was mixed by hand twice a day for 1.7, 19, and 24.6 hours, 4.8 and 13 days, and 6.3 months. The solids were separated from the liquids by passing the liquids through a $0.1-\mu \mathrm{m}$ syringe filter and analyzed for ${ }^{14} \mathrm{C}$ concentrations by liquid scintillation counting. No acid preservative was added to the sample because of the anionic character of the ${ }^{14} \mathrm{C}$-carbonate.

The $\mathrm{K}_{\mathrm{d}}$ value was calculated as follows:

$\mathrm{K}_{\mathrm{d}}=\left(\mathrm{cpm}\right.$ nosolid controls $\left.-\mathrm{cpm}_{\text {in solution }}\right) /\left(\mathrm{cpm}_{\text {in solution }} *(\right.$ particle weight $\left.(\mathrm{g}) / \operatorname{volume}(\mathrm{L}))\right)$ 
where cpm represents counts per minute.

\subsection{METHODS FOR THE DESORPTION EXPERIMENT}

${ }^{14} \mathrm{C}$ desorption experiments were conducted with the clayey sediment and cementitious materials that had been equilibrated with ${ }^{14} \mathrm{C}$-carbonate for four days. Approximately $8 \mathrm{~mL}$ of $0.1 \mathrm{M}$ solutions of $\mathrm{NaNO}_{3}, \mathrm{Na}_{2} \mathrm{CO}_{3}$, or $\mathrm{Na}_{2} \mathrm{HPO}_{4} * 7 \mathrm{H}_{2} \mathrm{O}$ were added to the solids in the centrifuge tubes. For two weeks these tubes were then mixed twice a day by shaking by hand. The solid and aqueous phases were then separated and the aqueous phase was passed through a $0.1-\mu \mathrm{m}$ filter and analyzed for ${ }^{14} \mathrm{C}$ by liquid scintillation.

Table 2. Sediment characterization.

\begin{tabular}{|c|c|c|c|c|}
\hline & Units & $\begin{array}{c}\text { Red } \\
\text { Subsurface } \\
\text { Clayey } \\
\text { Sediment }\end{array}$ & $\begin{array}{c}\text { Yellow } \\
\text { Subsurface } \\
\text { Sandy } \\
\text { Sediment }\end{array}$ & Analytical Method \\
\hline Sand / Silt / Clay & $\mathrm{Wt}-\%$ & $13 / 30 / 58$ & $1 / 2 / 97$ & $\begin{array}{l}\text { Pipette and sieve method (Miller and } \\
\text { Miller, 1987) }\end{array}$ \\
\hline Surface Area & $\mathrm{m}^{2} / \mathrm{g}$ & 15.31 & 2.4 & $\begin{array}{l}\text { B.E.T. (Brunauer, Emmett and } \\
\text { Teller, 1938) }\end{array}$ \\
\hline $\mathrm{pH}$ & & 4.55 & 5.1 & 1:1 sediment:water \\
\hline Organic Matter & $\mathrm{Wt}-\%$ & $<0.02$ & $<0.02$ & Combustion (Allen, 1986, pp. 15-16) \\
\hline Extractable Fe & Wt-\% & 1.50 & 0.72 & $\begin{array}{l}\text { Citrate-dithionate method (Sparks } \\
\text { 1996, pp. 647-648) }\end{array}$ \\
\hline $\mathrm{CEC}^{\mathrm{a}}$ & $\mathrm{cmol}_{+} / \mathrm{kg}$ & 1.09 & NA & $\begin{array}{l}\text { Unbuffered Salt Extraction Method } \\
\text { (Sparks 1996, pp. 1218-1220) }\end{array}$ \\
\hline $\mathrm{AEC}^{\mathrm{a}}$ & $\mathrm{cmol}-/ \mathrm{kg}$ & 1.58 & 0.06 & $\begin{array}{l}\text { Unbuffered Salt Extraction Method } \\
\text { (Sparks 1996, pp. 1218-1220) }\end{array}$ \\
\hline
\end{tabular}

Table 3. Characterization of the cementitious materials used in studies.

\begin{tabular}{|l|c|c|c|}
\hline $\begin{array}{l}\text { Cementitious } \\
\text { Materials }\end{array}$ & $\begin{array}{c}\text { BET surface } \\
\text { Area }\left(\mathbf{m}^{2} / \mathbf{g}\right)\end{array}$ & $\begin{array}{c}\text { pH } \\
(1: 1 \text { water:cement })\end{array}$ & $\begin{array}{c}\text { Eh } \\
(\mathbf{m} \text {; } \mathbf{1 : 1} \text { water:cement })\end{array}$ \\
\hline Reducing Grout & $7.11 \pm 0.02$ & 11.16 & 36 \\
\hline 36-yr- old Concrete & $5.88 \pm 0.02$ & 11.99 & 347 \\
\hline
\end{tabular}


Table 4. Reducing grout formulation. ${ }^{\text {a }}$

\begin{tabular}{|c|c|}
\hline Ingredient & Amount Added \\
\hline Slag & $210 \mathrm{lb} / \mathrm{yd}^{3}$ \\
\hline Water & 60 gallons $/ \mathrm{yd}^{3}$ \\
\hline Portland cement & $75 \mathrm{lb} / \mathrm{yd}^{3}$ \\
\hline Fly ash & $375 \mathrm{lb} / \mathrm{yd}^{3}$ \\
\hline sand & $2300 \mathrm{lb} / \mathrm{yd}^{3}$ \\
\hline KelcoCrete & $90 \mathrm{oz} / \mathrm{yd}^{3}$ \\
\hline Sodium thiosulfate & $2.1 \mathrm{lb} / \mathrm{yd}^{3}$ \\
\hline \multicolumn{2}{|c|}{$\begin{array}{l}\text { a Reducing grout sample prepared by Chrisine Langton } \\
\text { (SRNL) and identified as sample OPDEXE-X-P-O-BS. }\end{array}$} \\
\hline
\end{tabular}

\subsection{RESULTS AND DISCUSSION OF GEOCHEMISTRY EXPERIMENTS}

\section{1 (AD)SORPTION EXPERIMENT}

Sorption of ${ }^{14} \mathrm{C}$-carbonate on SRS subsurface clay sediment increased from the initial $(\mathrm{t}=0.07 \mathrm{~d})$ to second contact time point $(\mathrm{t}=0.8 \mathrm{~d}$ ) (Figure 2$)$. There was no statistical difference in ${ }^{14} \mathrm{C}$ carbonate sorption between the next four time points $(\mathrm{t}=0.8-13.1 \mathrm{~d})$, but a substantial increase in sorption was measured between 13.1 days and 189.2 days (6.3 months), at which time nearly $95 \%$ sorption was measured. ${ }^{14} \mathrm{C}$-carbonate sorption to the sand subsurface sediment (Figure 3 ) was more erratic between 0.07 to 13.1 days, but a significant increase was measured between 13.1 and 189.2 days, when $40 \%$ of the ${ }^{14} \mathrm{C}$-carbonate was sorbed. The respective $\mathrm{K}_{\mathrm{d}}$ values for clay and sand at 189.2 days (6.3 months) were $372 \mathrm{~mL} / \mathrm{g}$ and $8.64 \mathrm{~mL} / \mathrm{g}$. If these values are normalized by surface area (Table 2), the resulting $\mathrm{K}_{\mathrm{d}}$ values are $24.3 \mathrm{~mL} / \mathrm{m}^{2}$ for clay and 3.6 $\mathrm{mLl} / \mathrm{m}^{2}$ for sand. Therefore the surface area correction reduced the difference between the $\mathrm{K}_{\mathrm{d}}$ values; clayey sediment had a weight-normalized $\mathrm{K}_{d}$ value and a surface-area normalized $\mathrm{K}_{\mathrm{d}}$ value that was 43 and 7 times greater than that for the sandy sediment, respectively.

The sorption of ${ }^{14} \mathrm{C}$-carbonate to 36 -year-old concrete (Figure 4) increased during the first day and then remained constant for the ensuing two weeks. Between the 13.1 and 189.2 day measurements, nearly all the remaining ${ }^{14} \mathrm{C}$-carbonate was sorbed. The trend of ${ }^{14} \mathrm{C}$-carbonate sorption to the 36-year-old concrete was similar to that for the clayey sediment (Figure 2). ${ }^{14} \mathrm{C}$ carbonate sorption to the reducing grout (Figure 5) followed a similar trend as observed with the 36-year-old concrete, with a significant increase in sorption measured between 13.1 and 6.3 months. However, only $25 \%$ of the added ${ }^{14} \mathrm{C}$-carbonate sorbed to the reducing grout (Figure 5 ), which was the lowest percentage for all of the solids tested here. 
Solids concentrations for the cementitious solids were a factor of 10 lower than for sediments because it was anticipated the former would have greater sorption affinities for ${ }^{14} \mathrm{C}$-carbonate. The reason for the lower sorption of the reducing grout is not known. The major difference between reducing grout and the 36-year-old concrete is the presence of a reducing agent, slag, in the former. It is not clear why slag would cause carbonate sorption to decrease, given that the two $\mathrm{pH}$ levels were nearly identical at $\mathrm{pH} 11$ (Table 3). Yet, under our experimental conditions (i.e., not 1:1 water: solid as in Table 3), there was a significant difference in $\mathrm{pH}$ with values of 89 for cement and $\mathrm{pH}$ 5-6 for slag-containing cement. While the slag is not expected to reduce carbonate, perhaps the presence of the slag anions and cations influenced carbonate sorption.

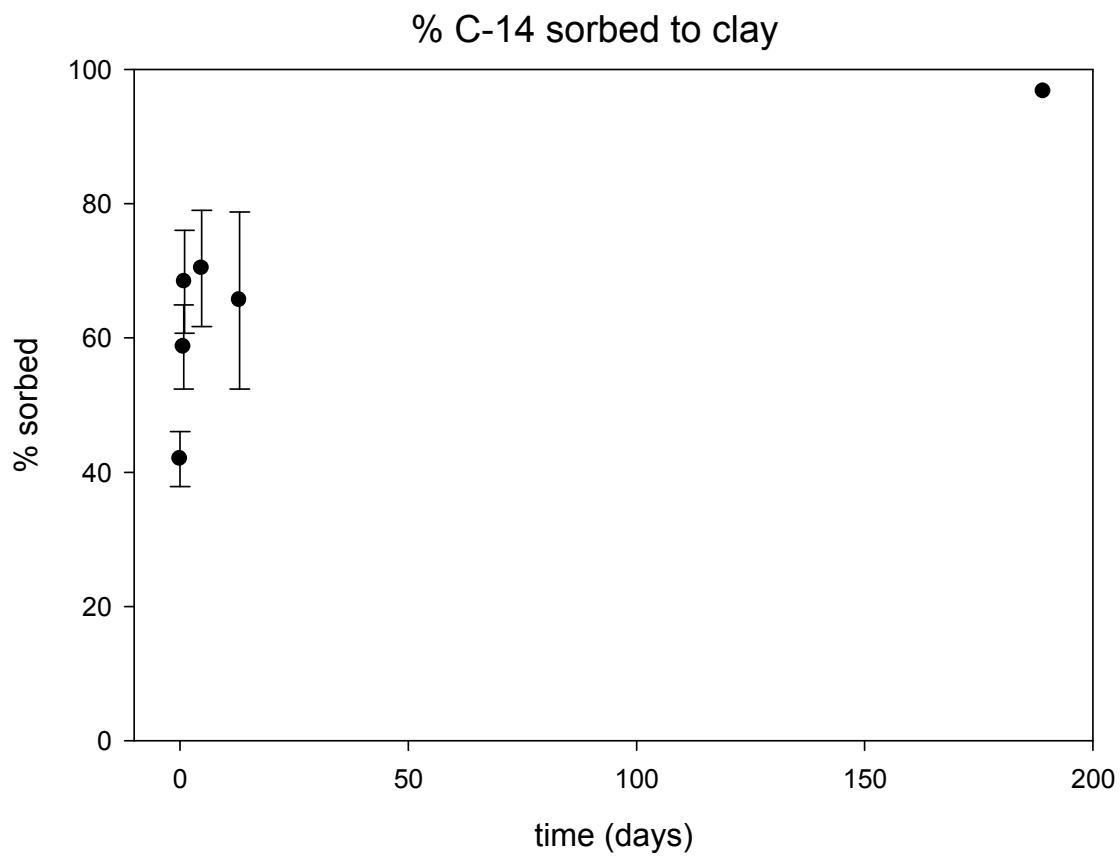

Figure 2. Percent of ${ }^{14} \mathrm{C}$, added as $\mathrm{Na}_{2}{ }^{14} \mathrm{CO}_{3}$, sorbed to clay particles as a function of time with a particle concentration of $83.3 \mathrm{mg} / \mathrm{L}$. Each data point represents the average of replicate measurements (except for time $=180$ days, $n=1$ ) and the error bar represents propagated counting uncertainty. 
$\%$ C-14 sorbed to sand

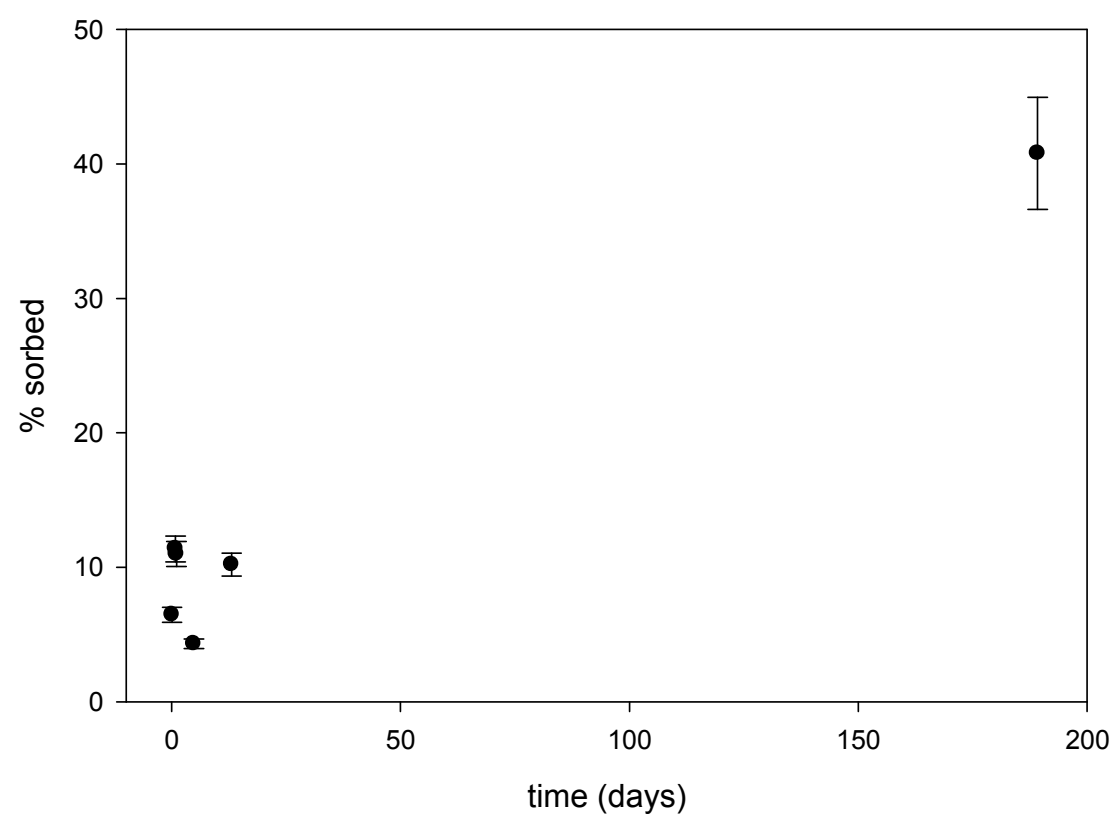

Figure 3. Percent of ${ }^{14} \mathrm{C}$, added as $\mathrm{Na}_{2}{ }^{14} \mathrm{CO}_{3}$, sorbed to sand particles as a function of time with a particle concentration of $83.3 \mathrm{mg} / \mathrm{L}$. Each data point represents the average of replicate measurements and the error bar is propagated counting uncertainty.

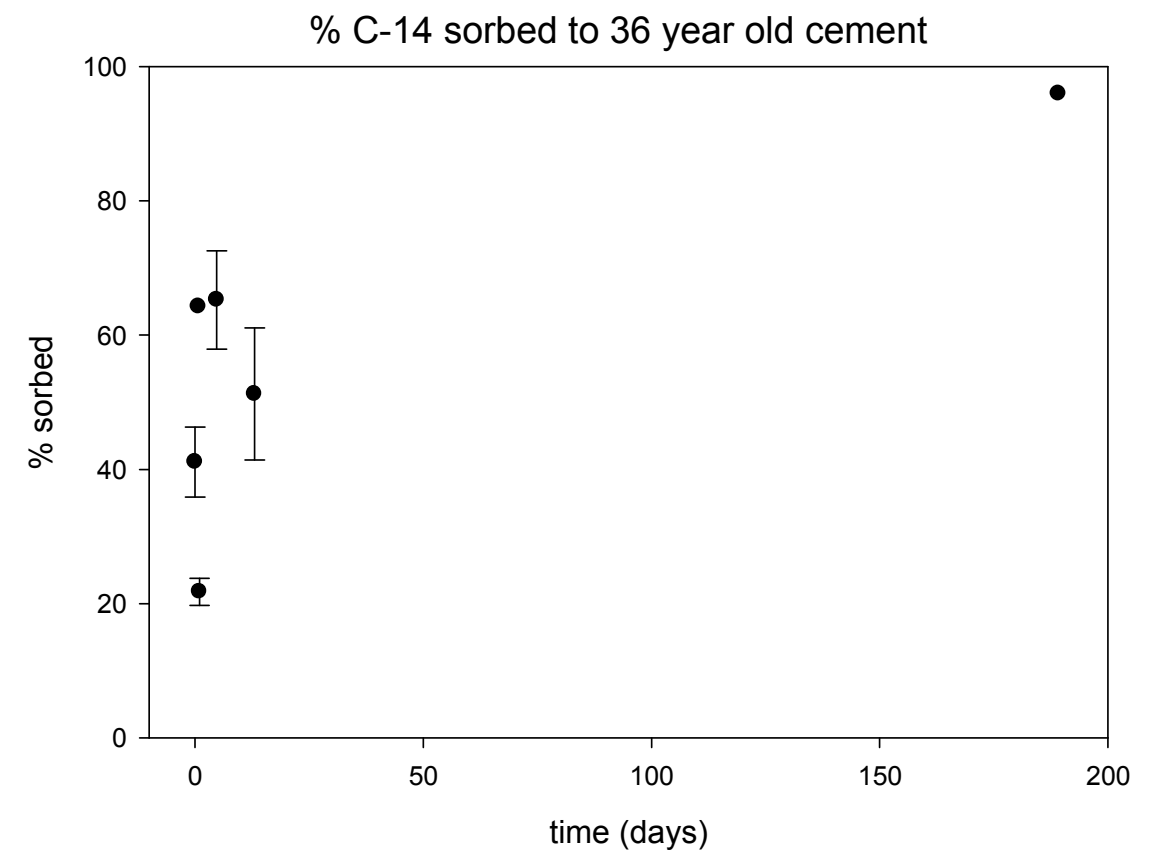

Figure 4. Percent of ${ }^{14} \mathrm{C}$, added as $\mathrm{Na}_{2}{ }^{14} \mathrm{CO}_{3}$, sorbed to 36-year-old concrete as a function of time with a particle concentration of $8.3 \mathrm{mg} / \mathrm{L}$. Each data point represents the average of replicate measurements (except for time $=\mathbf{1 8 0}$ days, $\mathbf{n}=1$ ) and the error bar is propagated counting uncertainty. 


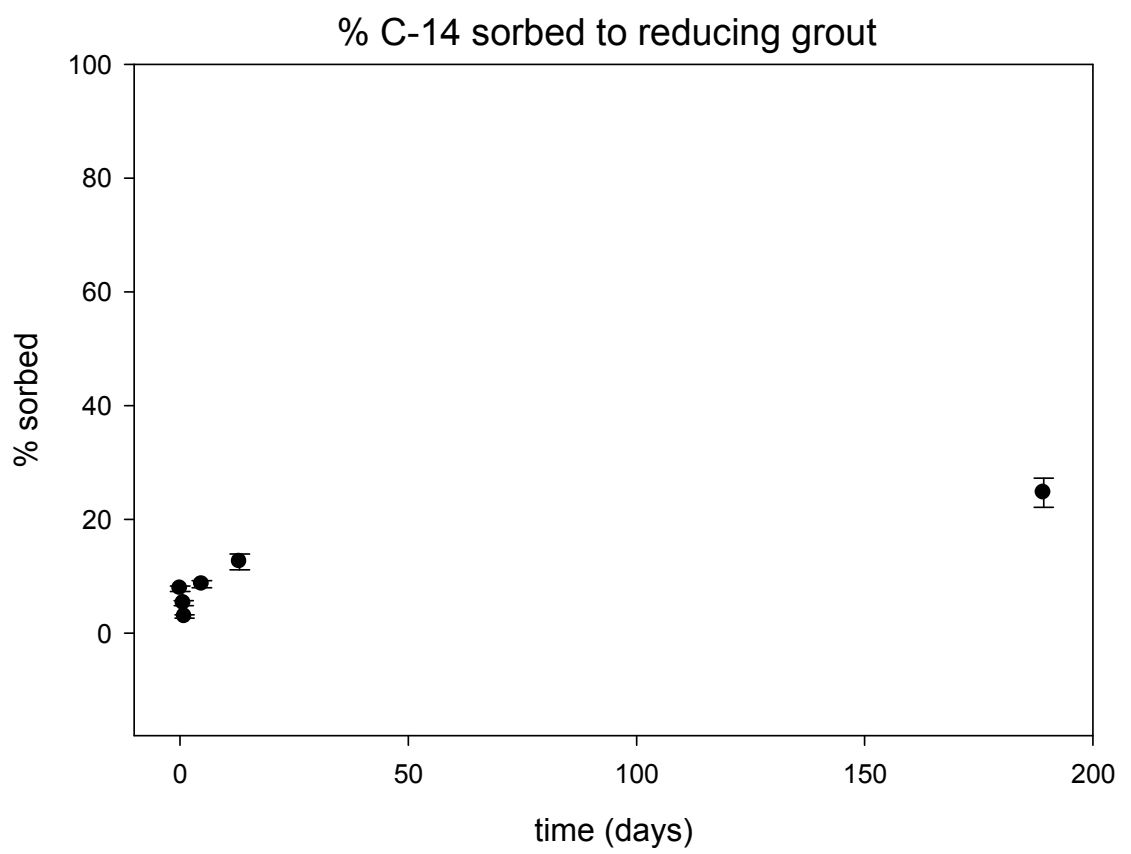

Figure 5. Percent of ${ }^{14} \mathrm{C}$, added as $\mathrm{Na}_{2}{ }^{14} \mathrm{CO}_{3}$, sorbed to reducing grout particles as a function of time with a particle concentration of $8.3 \mathrm{mg} / \mathrm{L}$. Each data point represents the average of replicate measurements and the error bar is the propagated counting uncertainty.

These results can also be presented in the form of $\mathrm{K}_{\mathrm{d}}$ values (Table 5). The data shows roughly the same trends as Figure 2 through Figure 5 though the propagated errors in the $\mathrm{K}_{\mathrm{d}}$ 's indicate less of a significance, especially in the first 5 data points (up to 13.1d). As stated above, the system was never demonstrated to have achieved complete steady state (This is demonstrated by measuring no change in aqueous ${ }^{14} \mathrm{C}$ concentrations (or $\mathrm{K}_{\mathrm{d}}$ values) for the last two or three contact durations), even after 6.3 months of equilibration. The $K_{d}$ values at 6.3 months may or may not be at equilibrium, a condition assumed for the $K_{d}$ construct, and as such, these values either represent or underestimate the true steady-state $K_{d}$ values.

Table 5. $K_{d}$ data for ${ }^{14} \mathrm{C}$-carbonate $(\mathrm{mL} / \mathrm{g})$ on different solids as a function of time

\begin{tabular}{|l|c|c|c|c|c|c|}
\hline Solid & $\mathbf{1 . 7 h}$ & $\mathbf{1 9 . 1 h}$ & $\mathbf{2 4 . 6 h}$ & $\mathbf{4 . 8 d}$ & $\mathbf{1 3 . 1 d}$ & $\mathbf{6 . 3 m}$ \\
\hline SRS clayey subsurface sediments & $9.68 \pm$ & $17.9 \pm$ & $27.6 \pm$ & $29.9 \pm$ & $24.3 \pm$ & $>372 \pm$ \\
& 2.1 & 2.8 & 3.9 & 4.47 & 3.48 & - \\
\hline SRS sandy subsurface sediments & $0.86 \pm$ & $1.62 \pm$ & $1.54 \pm$ & $0.56 \pm$ & $1.43 \pm$ & $8.64 \pm$ \\
& 1.2 & 1.3 & 1.2 & 1.1 & 1.2 & 1.9 \\
\hline 36-year Old Concrete & $242 \pm$ & $220.0 \pm$ & $33.5 \pm$ & $229.0 \pm$ & $197 \pm$ & $>2850 \pm$ \\
& 613 & 23.0 & 14.7 & 33.9 & 36.7 & - \\
\hline Reducing Grout & $1.78 \pm$ & $6.77 \pm$ & $3.75 \pm$ & $11.2 \pm$ & $17.1 \pm$ & $39.2 \pm$ \\
& 2.27 & 10.7 & 11.4 & 12.2 & 10.6 & 14.7 \\
\hline
\end{tabular}




\subsection{DESORPTION EXPERIMENT}

In all but one of the six desorption experiments very little ${ }^{14} \mathrm{C}$-carbonate was desorbed from the solid phase into solution (Figure 6). The one exception was the case of phosphate addition to the 36-year-old concrete. It should be noted that a much greater phosphate concentration was used in this study than is expected in the SRS subsurface. High anion concentrations were selected to provide insight into how strongly the ${ }^{14} \mathrm{C}$-carbonate was retained by these various solid phases. The desorption experiment demonstrated that the ${ }^{14} \mathrm{C}$-carbonate was sorbed strongly to the sediment and cementitious materials surfaces, even in the presence of extraordinarily high competing anion concentrations (except phosphate). The competition between phosphate and carbonate has been studied previously on mineral surfaces (Rahnemaie et. al., 2007). Rahnemaie et. al., (2007) reported finding that phosphate outcompetes carbonate especially at higher $\mathrm{pH}$ values. The $\mathrm{pH}$ of the cement-water mixture was between 8 and 9 , whereas the clay-water mixture was between $\mathrm{pH} 5$ and 6. Thus, phosphate is likely outcompeting the carbonate only in the case of the cement where the $\mathrm{pH}$ is higher and the phosphate is known to sorb more strongly. Although the rates of desorption were not measured, it can be qualitatively seen from this work that desorption is appreciably slower than adsorption (Figure 2 through Figure 5).

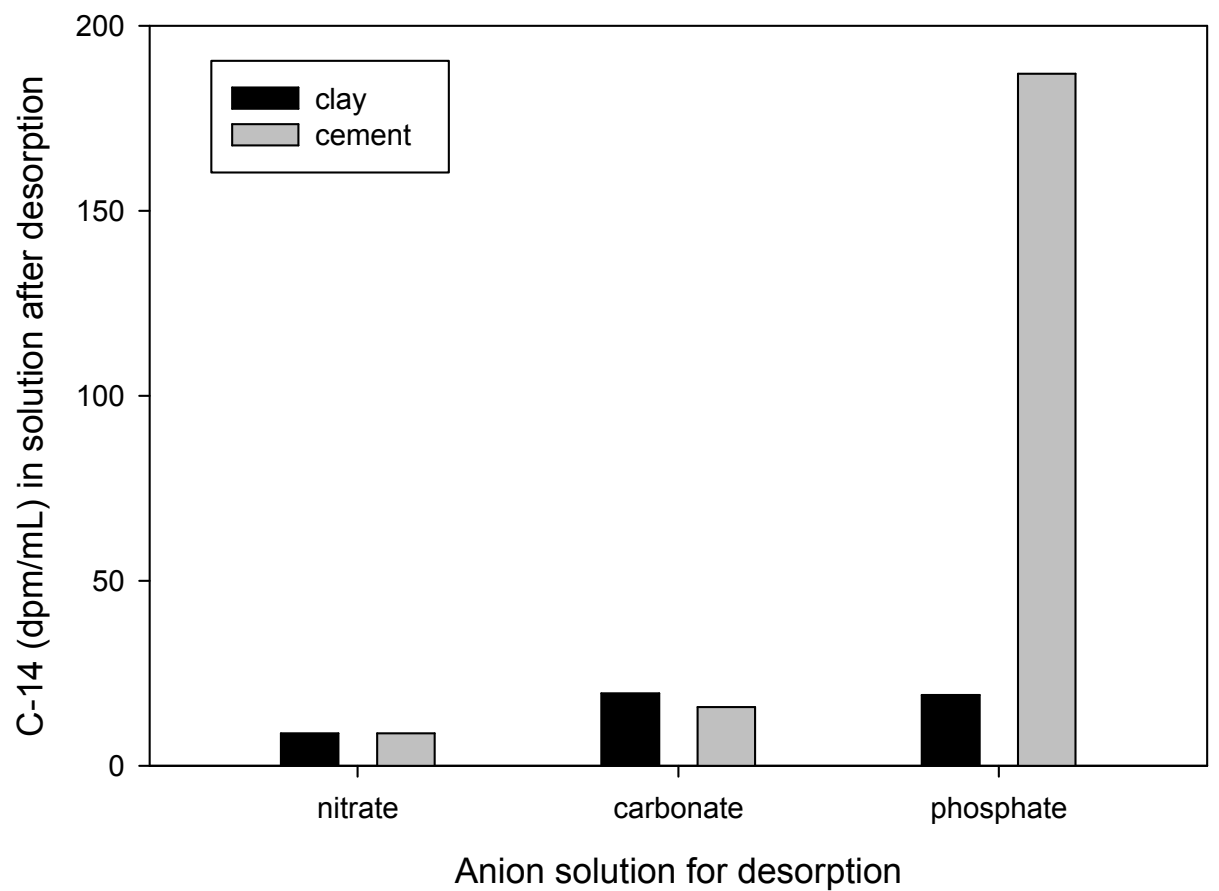

Figure 6. Activity of ${ }^{14} \mathrm{C}$-carbonate in solution after desorption experiment in $0.01 \mathrm{M}$ anion (nitrate, carbonate or phosphate) solutions to assess competitive replacement. 
For the desorption experiments, the amount of competing anion sorbed by the clayey sediment and 36-year-old concrete is presented in Figure 7. In the presence of the clayey sediment approximately $10 \%$ of the nitrate and carbonate were sorbed. In the presence of 36-year-old concrete, $10 \%$ of carbonate and $5 \%$ of nitrate was sorbed. Unexpectedly, the addition of phosphate resulted in the release of some phosphate from the solids, consequently a negative sorption of phosphate, i.e., desorption of phosphate, was measured.

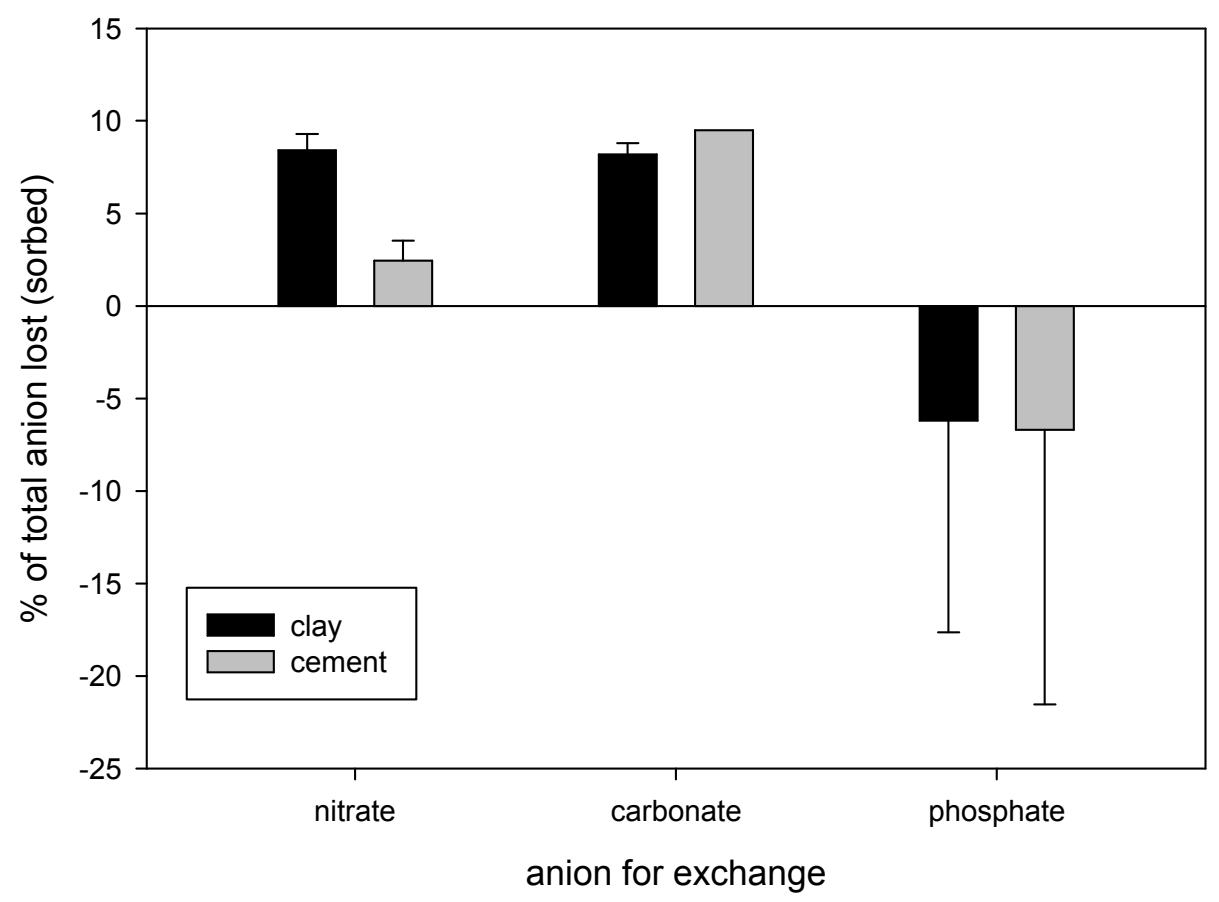

Figure 7. Percent of anion sorbed by the clayey sediment and the 36-year-old concrete during the desorption experiment. About 0.01M anion solution was added of each anion. The negative phosphate values indicate that some phosphate was desorbed from the solid phases upon adding phosphate to the suspensions. 


\subsection{CONCLUSIONS}

Sorption of ${ }^{14} \mathrm{C}$-carbonate on four solid phases relevant to $\mathrm{SRS}$ performance assessments increased over a 189.2 day (6.3 month) period. ${ }^{14} \mathrm{C}$-carbonate approached $95 \%$ sorption on clayey sediment and 36-year-old concrete samples during this 6.3 month period and appeared to have a lower sorption affinity for the sandy sediment (40\%), and even lower sorption affinity for the reducing grout $(25 \%)$. On all four substrates, the $\mathrm{K}_{\mathrm{d}}$ values at 6.3 months were clearly much greater than $0 \mathrm{~mL} / \mathrm{g}$, ranging from $8.6 \mathrm{~mL} / \mathrm{g}$ for the sandy sediment to $>2800$ for the aged concrete. Though it is not clear from the data that sorption equilibrium was achieved, estimates for the apparent $\mathrm{K}_{\mathrm{d}}$ values after 6.3 months are as follows: $3000 \mathrm{~mL} / \mathrm{g}$ for clayey sediments, 10 $\mathrm{mL} / \mathrm{g}$ for sandy sediments, $30,000 \mathrm{~mL} / \mathrm{g}$ for concrete and $40 \mathrm{~mL} / \mathrm{g}$ for reducing grout. It was also demonstrated that sorption and desorption rates were different and that the ${ }^{14} \mathrm{C}$-carbonate was strongly sorbed onto both clayey sediment and the 36-year-old concrete, indicating that a kinetic sorption model, as oppose to the steady-state $\mathrm{K}_{\mathrm{d}}$ model, may be a more accurate description of the ${ }^{14} \mathrm{C}$-carbonate sorption process.

There are a number of assumptions that transport modelers are required to make in order to incorporate the convenient $\mathrm{K}_{\mathrm{d}}$ construct, including that the rate of adsorption is equal to the rate of desorption, sorption does not change as a function of radionuclide concentration, and the system is at steady state (equilibrium; i.e., that a radionuclide is in contact with soil sufficiently long to permit steady state chemical conditions to exist). Data from this study suggest that the last assumption is not appropriate for ${ }^{14} \mathrm{C}$-carbonate geochemistry. Instead, as groundwater moves through the subsurface sediment (i.e., water pore velocities in the range of 0.5 to 1.0 $\mathrm{ft} /$ day are quite typical in SRS sandy sediments), ${ }^{14} \mathrm{C}$ 's contact time, in the order of a day, is not sufficiently long to permit steady state to occur. Ideally a kinetic sorption model would be used, but given the limitations of the existing SRS PA models, an "apparent $\mathrm{K}_{\mathrm{d}}$ value" after 1 day contact time may be more appropriate than a $\mathrm{K}_{\mathrm{d}}$ value at steady state, $>6.3$ months. This would be an "apparent $\mathrm{K}_{\mathrm{d}}$ value" because it is not truly at steady state. Apparent $\mathrm{K}_{\mathrm{d}}$ values for sandy sediment would be $1 \mathrm{~mL} / \mathrm{g}$, and for clayey sediment, $30 \mathrm{~mL} / \mathrm{g}$.

Figure 8 graphically compares these clayey and sandy apparent $\mathrm{K}_{\mathrm{d}}$ values versus the recommended values above. Early transient effects for sandy sediments appear to be quite small for sandy sediments; however, for clayey sediments a clear transient effect is present for the first day to 1.5 day time period. Pore velocities in clayey sediments will be much slower than in sandy sediments suggesting that the average value of $30 \mathrm{ml} / \mathrm{g}$ may be appropriate. To better define an apparent $\mathrm{K}_{\mathrm{d}}$ value for clayey sediments, as mentioned above, a transport analysis employing a local kinetic sorption model should be considered. 
SRNS-STI-2008-00445, REVISION 1

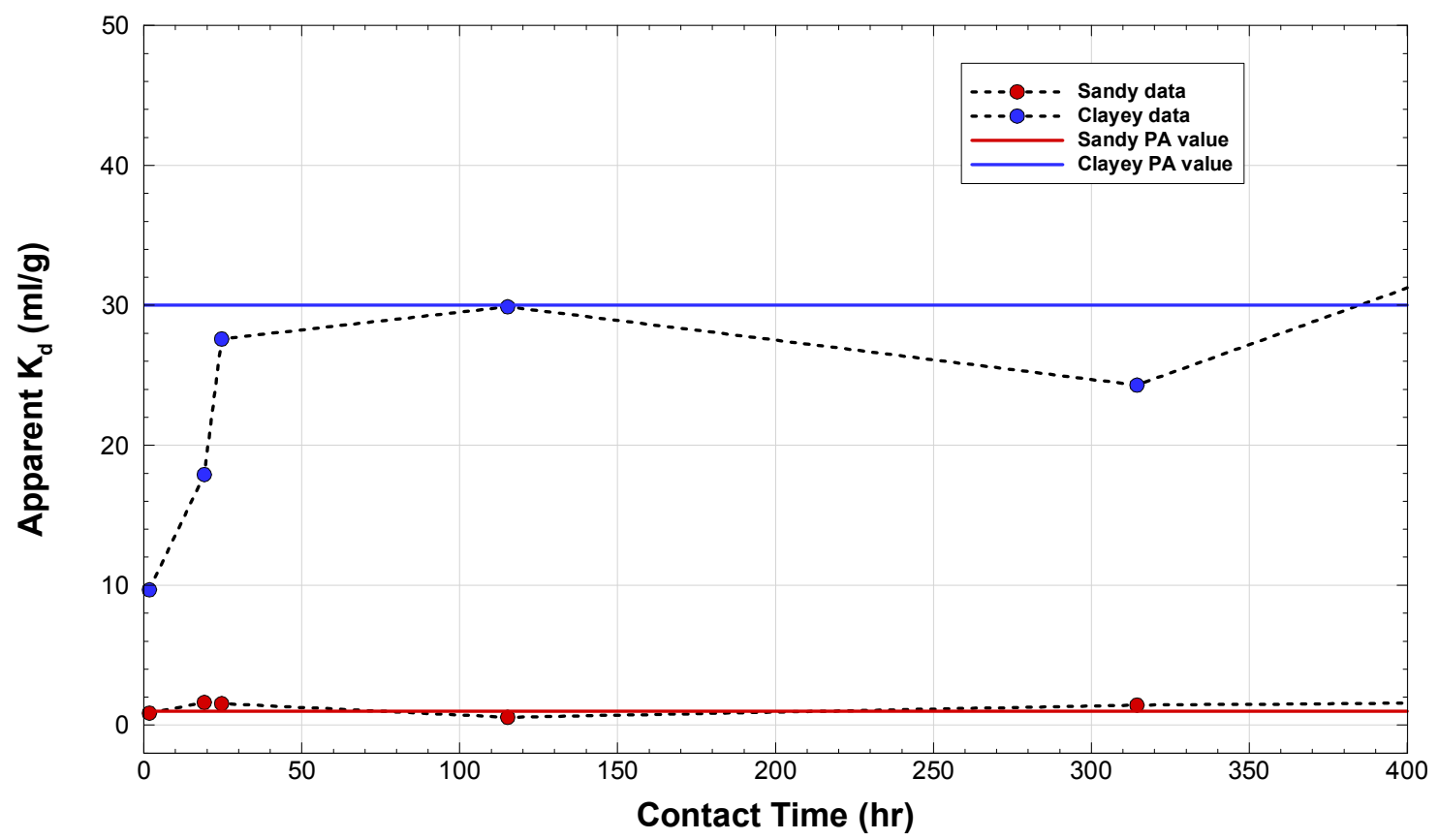

Figure 8. Comparison of Apparent $K_{d}$ values for SRS Sandy and Clayey sediments versus recommended value for use in $\mathrm{PA}$ analyses for $\mathrm{C}-14$. 
SRNS-STI-2008-00445, REVISION 1

\subsection{REFERENCES}

Allard, B., B. Torstenfelt, and K. Anderson. 1981. Sorption studies of $\mathrm{H}^{14} \mathrm{CO}_{3}{ }^{-}$on some geologic media and concrete. In Scientific Basis for Nuclear Waste Management. Vol 3. pp 465-472. Plenum Press, New York.

Allen, S. E. 1987. Chemical Analysis of Ecological Materials, Wiley Inter-Science, New York (pp. 15-16).

Brunauer, S., P. H. Emmett, and E. Teller. 1938. Adsorption of gases in multimolecular layers. $J$. Am. Chem. Soc., 60, 309-319.

Drever, J.I. 1997. The Geochemistry of Natural waters: Surface and Groundwater Environments. $3^{\text {rd }}$ Ed. Prentice Hall, NJ.

Hiergesell, R. A., M. A. Phifer, J. R. Cook, K. Young, M. Birk, and B. Dean. 2008. Inventory of Projected Residual Radioactivity at the Savannah River Site End State. SRNL-STI-200800380. Savannah River National Laboratory, Aiken, SC.

Kaplan, D. I. 2006. Geochemical Data Package for Performance Assessment Calculations Related to the Savannah River Site. WSRC-TR-2006-00004, Rev. 0. Savannah River National Laboratory, Aiken, SC.

Kaplan, D. I. 2010. Geochemical Data Package for Performance Assessment Calculations Related to the Savannah River Site. SRNL-STI-2009-0047. Savannah River National Laboratory, Aiken, SC.

Kaplan, D. I., and C. Coffey. 2002. Distribution Coefficients ( $\mathrm{K}_{\mathrm{d}}$ Values) for Waste Resins Generated from the K \& L Disassembly Basin Facilities. WSRC-TR-2002-00349, Rev. 0, Washington Savannah River Company, Savannah River Site, Aiken, SC.

Krupka, K. M., D. I. Kaplan, G. Whelan, R. J. Serne, and S. V. Mattigod. 1999. Understanding Variation in Partition Coefficient, $\mathrm{K}_{\mathrm{d}}$, Values. Volume 1: The $\mathrm{K}_{\mathrm{d}}$ Model, Methods of Measurement, and Application of Chemical Reaction Codes. EPA 402-R-99-004A. Office of Air and Radiation, Office of Solid Waste and Emergency Response, U.S. Environmental Protection Agency, Washington, DC. (http://www.epa.gov/radiation/cleanup/partition.htm)

Miller, W. P., and D. M. Miller. 1987. A micro-pipette method for soil mechanical analysis. Commun. Soil Sci. Plant Anal. 18(1):1-15.

McIntyre, P. F. 1988. Sorption properties of carbon-14 on Savannah River Plant Soil. DPST88-900. E. I. DuPont de Nemours and Co. Savannah River Plant, Aiken, SC.

Plummer, M. A., Hull, L. C., Fox, D. T. 2004. Transport of carbon-14 in a large unsaturated soil column. Vadose Zone Journal, 3:109-121.

Rahnemaie, R., Hiemstra, T., and W. H. van Riemsdijk (2007). Carbonate adsorption on goethite in competition with phosphate. Journal of Colloid and Interface Science, 315, 415425.

Reeder, R. J. (Ed.) 1983. Carbonates: Mineralogy and Chemistry. Reviews in Mineralogy, Volume 11. Mineralogical Society of America, Washington, DC.

Roberts, K. A., and D. I. Kaplan 2008. Carbon-14 geochemistry at the Savannah River Site. SRNS-STI-2008-00445, Revision 0 (9 December 2008). Savannah River National Laboratory, Aiken, SC.

Spark, D. L. (Ed.) 1996. Methods of Soil Analysis Part 3-Chemical Methods. Soil Science Society of America, Madison, WI. 
SRNS-STI-2008-00445, REVISION 1

APPENDIX A. CARBON-14 RAW DATA AND RESEARCH AND DEVELOPMENT DIRECTIONS 


\title{
RESEARCH AND DEVELOPMENT DIRECTIONS: MEASURING SORPTION (K $)_{\text {) OF }}$ ${ }^{14}$ C ON SRS SOILS AND CEMENTITIOUS MATERIALS
}

\author{
PI: \\ 4/18/08 \\ HAP: \\ SRNL-EST-2006-00093 \\ Hazards: \\ Radionuclides

\section{Hazards Mitigation:} \\ Radionuclides: Follow training of Advanced Rad Worker

\section{Objective:}

1. Measure ${ }^{14} \mathrm{CO}_{3}{ }^{2-}$ sorption parameters, $\mathrm{K}_{\mathrm{d}}$, on SRS site soils and cementitious materials for applicable to subsurface contaminant transport calculations. There is very little information in the literature on this subject as it relates to acidic soils, as exists at the SRS.

2. Determine the sorption kinetics of ${ }^{14} \mathrm{CO}_{3}{ }^{2-}$ onto these surfaces to assure us that sorption is not kinetically hindered, compromising the application of the $\mathrm{K}_{\mathrm{d}}$ construct in reactive transport models. Literature indicates that there may be a significant kinetic component to $\mathrm{CO}_{3}{ }^{2-}$ sorption to sediments.

3. Determine how strongly the sorbed ${ }^{14} \mathrm{CO}_{3}{ }^{2-}$ is retained by these geo-sorbents. This will be accomplished by adding varying anions to systems where ${ }^{14} \mathrm{CO}_{3}{ }^{2-}$ is sorbed. The competitive anions will have varying valences and ionic radii: $\mathrm{NO}_{3}{ }^{-}$(ionic radius $=165 \mathrm{x}$ $\left.10^{-12} \mathrm{~m}\right), \mathrm{CO}_{3}{ }^{2-}$ (ionic radius $\left.=164 \times 10^{-12} \mathrm{~m}\right)$, and $\mathrm{PO}_{3}{ }^{3-}\left(\right.$ ionic radius $\left.=29 \times 10^{-12} \mathrm{~m}\right)$.

\section{Materials:}

1. SRS sandy subsurface sediment

2. SRS clayey subsurface sediment

3. Aged cementitious material (36-year old recovered from SRS structure)

4. Slag cementitious material

5. ${ }^{14} \mathrm{CO}_{3}{ }^{2-}$ spike solution (as sodium carbonate in $\left.0.001 \mathrm{M} \mathrm{NaOH}\right)(0.2 \mu \mathrm{Ci} / \mathrm{mL}$ or $440,000 \mathrm{dpm} / \mathrm{mL}$

6. uncontaminated SRS groundwater (Par Pond Groundwater)

7. $15 \mathrm{ml}$ centrifuge tubes

8. 10-mLdisposable syringes

9. $0.1 \mu \mathrm{m}$ or $0.45 \mu \mathrm{m}$ syringe filters

10. $25 \mathrm{~mm} 0.45 \mu \mathrm{m}$ filters and disposable housings for subset $(\mathrm{t}=24 \mathrm{~h})$ only

11. sample bottles; filter holders

12. $100 \mathrm{mM} \mathrm{NaNO}_{3}$ : Using a $100 \mathrm{~mL}$ volumetric flask, dissolve $0.85 \mathrm{~g}$ of $\mathrm{NaNO}_{3}$ into $\sim 80 \mathrm{~mL}$ of MilliQ water, then bring up to volume.

13. $100 \mathrm{mM} \mathrm{Na} \mathrm{CO}_{3}$ : Using a $100 \mathrm{~mL}$ volumetric flask, dissolve $1.06 \mathrm{~g}$ of $\mathrm{Na}_{2} \mathrm{CO}_{3}$ into $\sim 80 \mathrm{~mL}$ of MilliQ water, then bring up to volume.

14. $100 \mathrm{mM} \mathrm{NaH}{ }_{2} \mathrm{PO}_{4}-\mathrm{H}_{2} \mathrm{O}$ : Using a $100 \mathrm{~mL}$ volumetric flask, dissolve $1.38 \mathrm{~g}$ of $\mathrm{NaH}_{2} \mathrm{PO}_{4}-\mathrm{H}_{2} \mathrm{O}$ into $\sim 80 \mathrm{~mL}$ of MilliQ water, then bring up to volume. 


\section{Methods:}

\section{Sorption Tests (Objectives $1 \&$ 2)}

Equilibrating solids with groundwater. This experiment will have duplicate samples for each solid (sandy soil, clayey soil, cementitious material and slag cementitious material) and 6-repls for $\mathrm{t}=96 \mathrm{hour}$, as noted on Table 1 . Do not label and tare tubes in Table 2 - you will simply relabel these and use the tare weights entered in Table 1.

1. Label tubes and record tare weights (without caps) in Table 1.

2. Add $1 \pm 0.01 \mathrm{~g}$ of soil material (Tubes $301-328$ ) or $0.1 \pm 0.01 \mathrm{~g}$ of cementitious material (tubes 329 - 357) into $15 \mathrm{ml}$ centrifuge tubes. Weight and enter "Solid Wt." into Table 1.

3. Add $10 \mathrm{ml}$ ground water to each tube.

4. Place samples on shaker overnight.

5. The next day let solids settle, decant and be careful not to lose solids, error on side of leaving liquids in tube.

\section{Batch adsorption as a function of time}

6. Add $0.70 \mathrm{~mL}$ of ${ }^{14} \mathrm{CO}_{3}{ }^{2-}$ spike solution to $840 \mathrm{~mL}$ of Par Pond Groundwater.

7. Move pre-equilibrated solids to rad hood. Add $12 \mathrm{~mL}$ of ${ }^{14} \mathrm{CO}_{3}{ }^{2-}$ amended groundwater created in step 6. Also add $12 \mathrm{~mL}$ of this amended groundwater to the No-solids Controls (Tube ID \#358 359, \& 360). Weigh "Tube+Solid+Liq Wt" and record in Table 1. Record date/time in Table 1. Shake by hand all samples vigorously for 5 seconds.

8. Measure $\mathrm{pH}$ with litmus paper and record in Table 1 (soils will be $\mathrm{pH} \sim 4-5$, cements will be $\mathrm{pH} \sim 9-12$ ).

9. Shake 3x a day by hand for appropriate duration as indicated in Table 1 .

\section{Sorption sample separation}

10. Let solids settle (or centrifuge at $4000 \mathrm{rpm}$ for $10 \mathrm{~min}$ ), decant and be careful not to lose solids, error on side of leaving liquids in tube.

11. Carefully siphon supernatant from $15 \mathrm{ml}$ tube and pass through a $0.1 \mu \mathrm{m}$ syringe filter; collecting filtrate in sample bottle to be submitted to Analytical Development section for liquid scintillation counting of ${ }^{14} \mathrm{C}$. Record "Stop date/time" in Table 1.

12. Save solids (in $\mathrm{rad}$ hood) for use in the desorption experiment described below.

Solids Measurements for QA: Mass balance of $K_{d}{ }^{1}$ and Total Recovery of Rads on Solids

13. For samples 305, 306, 333, \& 334, separate solids from liquid by passing slurry through $25 \mathrm{~mm} 0.4 \mathrm{um}$ filter. Place filter disc and all the solids in labeled and tared (record in Table 1) liquid scintillation vial $(20 \mathrm{~mL})$. Be sure to include the soil weight that was transferred into the samples. Sample numbers are $405,406,433 \& 434$, corresponding to the liquid samples of 305 , $306,333, \& 334$, respectively. By combining the results of these analyses, we will directly measure $\mathrm{K}_{\mathrm{d}}$, as oppose to measuring sorbed by difference in the aqueous phase.

\footnotetext{
${ }^{1}$ We are testing the assumption that the amount of rad can be determined by measuring the amount remaining in the aqueous phase before and after the study. In these steps of the experiment we are preparing solids for direct measurement by liquid scintillation counting: $\mathrm{Kd}=\mathrm{A}_{\mathrm{solid}} / \mathrm{A}_{\mathrm{aq}}$.
} 
14. Add $1 \mathrm{~g}$ of clayey sediment to a tube labeled \#401 and $0.1 \mathrm{~g}$ of cement to a tube labeled \#402. Add $10 \mathrm{~mL}$ groundwater. Shake vigorously. Pass through a $0.45 \mu \mathrm{m}$ filter. Place filters and solids into tared sample tubes (tubes you will submit to ADS) label \#401 and \#402. Add $10 \mu \mathrm{L}$ of ${ }^{14} \mathrm{C}$ spike solution to solid on filter.

15. Submit these six solid samples to Analytical Development section for liquid scintillation counting of ${ }^{14} \mathrm{C}$. It may require that we submit these under separate Travel Copies because these are solid samples, compared to the rest of the samples being aqueous samples.

\section{Desorption Experiments}

16. Move tubes $309-314$ and $337-342$ into the same rack. Re-label them as shown in Table 2.

17. Add $8 \mathrm{~mL}$ of appropriate $\mathrm{NaNO}_{3}, \mathrm{Na}_{2} \mathrm{CO}_{3}$, or $\mathrm{Na}_{3} \mathrm{HPO}_{3}$ solution, as designated in Table 2 . Shake sample vigorously my hand for 5 seconds. Weigh and record weight in Table 2.

18. Measure $\mathrm{pH}$ with litmus paper and record in Table 2.

19. Shake by hand $3 \mathrm{X}$ a day, at the beginning and end of the work day for one week.

20. Let solids settle to separate solids from liquids.

21. Carefully siphon supernatant from $15 \mathrm{ml}$ tube and pass through a $0.1 \mu \mathrm{m}$ syringe filter; collecting filtrate in sample bottle to be submitted to Analytical Development section for liquid scintillation counting of ${ }^{14} \mathrm{C}$ and for ion chromatography analysis for nitrate, carbonate, and phosphate analysis. 
Table A-1. Sample descriptions, experimental conditions and raw data for ${ }^{14} \mathrm{C}$ sorption and desorption experiments

\begin{tabular}{|c|c|c|c|c|c|c|c|c|c|c|}
\hline ID & SOLID & $\overline{\text { TIME }}$ & REP & $\begin{array}{c}\text { TARE } \\
\text { WT (G) }\end{array}$ & $\begin{array}{c}\text { SOLID } \\
\text { WT (G) }\end{array}$ & $\begin{array}{c}\text { TARE+SOLI } \\
\text { D+LIQ WT } \\
\text { (G) }\end{array}$ & $\begin{array}{c}\text { START } \\
\text { DATE/ TIME }\end{array}$ & $\begin{array}{c}\text { STOP } \\
\text { DATE/TIME }\end{array}$ & TIME & $\begin{array}{c}{ }^{14} \text { C AT } \\
\text { END OF } \\
\text { EXPT } \\
\text { (DPM/ML) }\end{array}$ \\
\hline & Step \# & & & 1 & 2 & 6 & 7 & 11 & & \\
\hline 301 & Clay & $\mathrm{t}=0.5 \mathrm{~h}$ & 1 & 5.43378 & 1.00053 & 19.044 & 4/23/2008 14:17 & 4/23/08 16:00 & 1.72 & $1.72 \mathrm{E}+02$ \\
\hline 302 & & & 2 & 5.46006 & 1.0017 & 19.046 & $4 / 23 / 200814: 17$ & $4 / 23 / 08 \quad 16: 00$ & 1.72 & $1.24 \mathrm{E}+02$ \\
\hline 303 & & $\mathrm{t}=8 \mathrm{~h}$ & 1 & 5.43111 & 1.00298 & 18.985 & 4/23/2008 14:17 & $4 / 24 / 089: 25$ & 19.13 & $1.13 \mathrm{E}+02$ \\
\hline 304 & & & 2 & 5.42024 & 1.00329 & 18.986 & $4 / 23 / 2008 \quad 14: 17$ & 4/24/08 9:25 & 19.13 & $9.79 \mathrm{E}+01$ \\
\hline 305 & & $\mathrm{t}=24 \mathrm{~h}$ & 1 & 5.40971 & 1.00134 & 19.506 & $4 / 23 / 2008 \quad 14: 17$ & $4 / 24 / 08 \quad 14: 55$ & 24.63 & $8.25 \mathrm{E}+01$ \\
\hline 306 & & & 2 & 5.45244 & 1.00554 & 19.041 & $4 / 23 / 200814: 17$ & $4 / 24 / 08 \quad 14: 55$ & 24.63 & $7.90 \mathrm{E}+01$ \\
\hline 307 & & $\mathrm{t}=48 \mathrm{~h}$ & 1 & 5.41195 & 1.0018 & 19.074 & $4 / 23 / 2008 \quad 14: 17$ & 4/28/08 9:25 & 115.13 & $7.39 \mathrm{E}+01$ \\
\hline 308 & & & 2 & 5.43011 & 1.00528 & 19.001 & $4 / 23 / 2008 \quad 14: 17$ & $4 / 28 / 089: 25$ & 115.13 & $7.73 \mathrm{E}+01$ \\
\hline 309 & & $t=96 h$ & 1 & 5.45033 & 1.00118 & 19.113 & $4 / 24 / 2008$ 10:05 & 5/7/08 12:00 & 313.92 & $7.74 \mathrm{E}+01$ \\
\hline 310 & & & 2 & 5.46006 & 0.99985 & 18.985 & $4 / 24 / 2008 \quad 10: 05$ & 5/7/08 12:00 & 313.92 & $9.11 \mathrm{E}+01$ \\
\hline 311 & & & 3 & 5.4257 & 0.99939 & 18.97 & $4 / 24 / 2008$ 10:05 & 5/7/08 12:00 & 313.92 & $1.03 \mathrm{E}+02$ \\
\hline 312 & & & 4 & 5.43819 & 1.00558 & 19.111 & $4 / 24 / 2008 \quad 10: 05$ & 5/7/08 12:00 & 313.92 & $9.22 \mathrm{E}+01$ \\
\hline 313 & & & 5 & 5.43576 & 1.0028 & 18.728 & $4 / 24 / 2008$ 10:05 & 5/7/08 12:00 & 313.92 & $8.59 \mathrm{E}+01$ \\
\hline 314 & & & 6 & 5.42366 & 1.00095 & 18.986 & 4/24/2008 10:05 & 5/7/08 12:00 & 313.92 & $7.71 \mathrm{E}+01$ \\
\hline 315 & & $\mathrm{t}=1 \mathrm{mo}$ & 1 & 5.44616 & 1.00868 & 19.277 & $4 / 24 / 2008$ 10:05 & 10/30/08 15:00 & 4540.92 & $<8.40 \mathrm{E}+00$ \\
\hline 316 & & & 2 & & & 19.074 & $4 / 24 / 2008$ 10:05 & 10/30/08 15:00 & 4540.92 & $<8.42 \mathrm{E}+00$ \\
\hline 317 & Sand & $\mathrm{t}=0.5 \mathrm{~h}$ & 1 & 5.63509 & 0.99731 & 19.066 & $4 / 23 / 200814: 17$ & $4 / 23 / 0816: 00$ & 1.72 & $2.36 \mathrm{E}+02$ \\
\hline 318 & & & 2 & 5.43704 & 1.00332 & 18.929 & $4 / 23 / 2008 \quad 14: 17$ & 4/23/08 16:00 & 1.72 & $2.41 \mathrm{E}+02$ \\
\hline 319 & & $\mathrm{t}=8 \mathrm{~h}$ & 1 & 5.62165 & 1.00687 & 19.203 & $4 / 23 / 2008 \quad 14: 17$ & $4 / 24 / 089: 25$ & 19.13 & $2.20 \mathrm{E}+02$ \\
\hline 320 & & & 2 & 5.49139 & 0.99907 & 19.06 & $4 / 23 / 2008 \quad 14: 17$ & $4 / 24 / 089: 25$ & 19.13 & $2.32 \mathrm{E}+02$ \\
\hline 321 & & $\mathrm{t}=24 \mathrm{~h}$ & 1 & 5.59132 & 1.00852 & 19.246 & $4 / 23 / 2008 \quad 14: 17$ & $4 / 24 / 08 \quad 14: 55$ & 24.63 & $2.29 \mathrm{E}+02$ \\
\hline 322 & & & 2 & 5.45095 & 1.00499 & 18.951 & $4 / 23 / 2008 \quad 14: 17$ & $4 / 24 / 08$ 14:55 & 24.63 & $2.25 \mathrm{E}+02$ \\
\hline 323 & & $\mathrm{t}=48 \mathrm{~h}$ & 1 & 5.59617 & 1.00747 & 19.103 & $4 / 23 / 2008 \quad 14: 17$ & 4/28/08 9:25 & 115.13 & $2.43 \mathrm{E}+02$ \\
\hline 324 & & & 2 & 5.47317 & 1.00587 & 18.971 & $4 / 23 / 2008 \quad 14: 17$ & $4 / 28 / 089: 25$ & 115.13 & $2.45 \mathrm{E}+02$ \\
\hline 325 & & $\mathrm{t}=96 \mathrm{~h}$ & 1 & 5.59937 & 1.00088 & 19.229 & $4 / 24 / 2008$ 10:05 & 5/7/08 12:00 & 313.92 & $2.27 \mathrm{E}+02$ \\
\hline 326 & & & 2 & 5.61906 & 1.00307 & 19.146 & $4 / 24 / 2008$ 10:05 & 5/7/08 12:00 & 313.92 & $2.31 \mathrm{E}+02$ \\
\hline 327 & & $\mathrm{t}=1 \mathrm{mo}$ & 1 & 5.60912 & 1.00847 & 19.251 & $4 / 24 / 2008$ 10:05 & 10/30/08 15:00 & 4540.92 & $1.48 \mathrm{E}+02$ \\
\hline 328 & & & 2 & 5.44521 & 1.00099 & 19 & 4/24/2008 10:05 & 10/30/08 15:00 & 4540.92 & $1.54 \mathrm{E}+02$ \\
\hline
\end{tabular}


SRNS-STI-2008-00445, REVISION 1

\begin{tabular}{|c|c|c|c|c|c|c|c|c|c|c|}
\hline ID & SOLID & TIME & REP & $\begin{array}{c}\text { TARE } \\
\text { WT (G) }\end{array}$ & $\begin{array}{l}\text { SOLID } \\
\text { WT (G) }\end{array}$ & $\begin{array}{c}\text { TARE+SOLI } \\
\text { D+LIQ WT } \\
\text { (G) }\end{array}$ & $\begin{array}{c}\text { START } \\
\text { DATE/ TIME }\end{array}$ & $\begin{array}{c}\text { STOP } \\
\text { DATE/TIME }\end{array}$ & TIME & $\begin{array}{c}{ }^{14} \text { C AT } \\
\text { END OF } \\
\text { EXPT } \\
\text { (DPM/ML) }\end{array}$ \\
\hline 329 & Cement & $\mathrm{t}=0.5 \mathrm{~h}$ & 1 & 5.56766 & 0.09975 & 18.236 & 4/23/2008 14:17 & 4/23/08 16:00 & 1.72 & $2.49 \mathrm{E}+02$ \\
\hline 330 & & & 2 & 5.56729 & 0.100008 & 17.83 & $4 / 23 / 2008 \quad 14: 17$ & 4/23/08 16:00 & 1.72 & $5.15 \mathrm{E}+01$ \\
\hline 331 & & $\mathrm{t}=8 \mathrm{~h}$ & 1 & 5.43688 & 0.09914 & 17.703 & $4 / 23 / 2008 \quad 14: 17$ & $4 / 24 / 089: 25$ & 19.13 & $9.12 \mathrm{E}+01$ \\
\hline 332 & & & 2 & 5.45196 & 0.10345 & 17.713 & $4 / 23 / 2008 \quad 14: 17$ & 4/24/08 9:25 & 19.13 & $2.27 \mathrm{E}+03$ \\
\hline 333 & & $\mathrm{t}=24 \mathrm{~h}$ & 1 & 5.43749 & 0.10276 & 17.655 & $4 / 23 / 2008 \quad 14: 17$ & $4 / 24 / 08 \quad 14: 55$ & 24.63 & $2.13 \mathrm{E}+02$ \\
\hline 334 & & & 2 & 5.43723 & 0.10306 & 17.701 & $4 / 23 / 2008 \quad 14: 17$ & $4 / 24 / 08 \quad 14: 55$ & 24.63 & $1.86 \mathrm{E}+02$ \\
\hline 335 & & $\mathrm{t}=48 \mathrm{~h}$ & 1 & 5.45014 & 0.1007 & 17.963 & $4 / 23 / 2008 \quad 14: 17$ & $4 / 28 / 089: 25$ & 115.13 & $8.18 \mathrm{E}+01$ \\
\hline 336 & & & 2 & 5.62069 & 0.10308 & 17.831 & $4 / 23 / 2008 \quad 14: 17$ & 4/28/08 9:25 & 115.13 & $9.55 \mathrm{E}+01$ \\
\hline 337 & & $\mathrm{t}=96 \mathrm{~h}$ & 1 & 5.41304 & 0.101161 & 17.678 & $4 / 24 / 2008$ 10:05 & 5/7/08 12:00 & 313.92 & $1.22 \mathrm{E}+02$ \\
\hline 338 & & & 2 & 5.43532 & 0.10374 & 17.829 & $4 / 24 / 200810: 05$ & 5/7/08 12:00 & 313.92 & $1.18 \mathrm{E}+02$ \\
\hline 339 & & & 3 & 5.59102 & 0.10106 & 17.605 & $4 / 24 / 2008$ 10:05 & 5/7/08 12:00 & 313.92 & $1.66 \mathrm{E}+02$ \\
\hline 340 & & & 4 & 5.55216 & 0.100149 & 17.832 & $4 / 24 / 2008$ 10:05 & 5/7/08 12:00 & 313.92 & $1.31 \mathrm{E}+02$ \\
\hline 341 & & & 5 & 5.4176 & 0.101661 & 18.728 & $4 / 24 / 2008$ 10:05 & 5/7/08 12:00 & 313.92 & $4.13 \mathrm{E}+01$ \\
\hline 342 & & & 6 & 5.43664 & 0.10517 & 17.716 & $4 / 24 / 2008$ 10:05 & 5/7/08 12:00 & 313.92 & $1.68 \mathrm{E}+02$ \\
\hline 343 & & $\mathrm{t}=1 \mathrm{mo}$ & 1 & 5.43582 & 0.1008 & 17.701 & $4 / 24 / 2008$ 10:05 & 10/30/08 15:00 & 4540.92 & $<1.03 \mathrm{E}+01$ \\
\hline 344 & & & 2 & 5.58685 & 0.10138 & 17.769 & $4 / 24 / 2008 \quad 10: 05$ & 10/30/08 15:00 & 4540.92 & $<1.03 \mathrm{E}+01$ \\
\hline 345 & Slag-cement & $\mathrm{t}=0.5 \mathrm{~h}$ & 1 & 5.61444 & 0.10082 & 18.013 & 4/23/2008 14:17 & 4/23/08 16:00 & 1.72 & $2.70 \mathrm{E}+02$ \\
\hline 346 & & & 2 & 5.61371 & 0.10029 & 17.888 & $4 / 23 / 200814: 17$ & $4 / 23 / 08 \quad 16: 00$ & 1.72 & $2.35 \mathrm{E}+02$ \\
\hline 347 & & $\mathrm{t}=8 \mathrm{~h}$ & 1 & 5.57255 & 0.10106 & 17.873 & $4 / 23 / 2008 \quad 14: 17$ & $4 / 24 / 089: 25$ & 19.13 & $2.41 \mathrm{E}+02$ \\
\hline 348 & & & 2 & 5.44971 & 0.10022 & 17.719 & $4 / 23 / 2008 \quad 14: 17$ & 4/24/08 9:25 & 19.13 & $2.42 \mathrm{E}+02$ \\
\hline 349 & & $t=24 h$ & 1 & 5.58325 & 0.1012 & 17.878 & $4 / 23 / 2008 \quad 14: 17$ & $4 / 24 / 08 \quad 14: 55$ & 24.63 & $2.46 \mathrm{E}+02$ \\
\hline 350 & & & 2 & 5.42593 & 0.10206 & 18.632 & $4 / 23 / 2008$ 14:17 & $4 / 24 / 08$ 14:55 & 24.63 & $2.49 \mathrm{E}+02$ \\
\hline 351 & & $\mathrm{t}=48 \mathrm{~h}$ & 1 & 5.43036 & 0.10189 & 17.647 & 4/23/2008 14:17 & $4 / 28 / 089: 25$ & 115.13 & $2.39 \mathrm{E}+02$ \\
\hline 352 & & & 2 & 5.41921 & 0.10336 & 17.691 & $4 / 23 / 2008$ 14:17 & $4 / 28 / 089: 25$ & 115.13 & $2.27 \mathrm{E}+02$ \\
\hline 353 & & $\mathrm{t}=96 \mathrm{~h}$ & 1 & 5.44168 & 0.1013 & 17.658 & $4 / 24 / 2008$ 10:05 & 5/7/08 12:00 & 313.92 & $2.29 \mathrm{E}+02$ \\
\hline 354 & & & 2 & 5.62307 & 0.10514 & 17.839 & 4/24/2008 10:05 & 5/7/08 12:00 & 313.92 & $2.15 \mathrm{E}+02$ \\
\hline 355 & & & 3 & 5.59433 & 0.1 & 17.801 & $4 / 24 / 2008$ 10:05 & 5/7/08 12:00 & 313.92 & $2.25 \mathrm{E}+02$ \\
\hline 356 & & $\mathrm{t}=1 \mathrm{mo}$ & 1 & 5.43045 & 0.10236 & 17.696 & 4/24/2008 10:05 & 10/30/08 15:00 & 4540.92 & $1.90 \mathrm{E}+02$ \\
\hline 357 & & & 2 & 5.53511 & 0.10114 & 17.754 & $4 / 24 / 2008$ 10:05 & 10/30/08 15:00 & 4540.92 & $1.94 \mathrm{E}+02$ \\
\hline 358 & No-Solids Control & $\mathrm{t}=96 \mathrm{~h}$ & 1 & 5.412 & 0 & 17.451 & $4 / 24 / 2008$ 10:05 & 5/7/08 12:00 & 313.92 & $2.61 \mathrm{E}+02$ \\
\hline 359 & & & 2 & 5.611 & 0 & 17.643 & $4 / 24 / 2008$ 10:05 & 5/7/08 12:00 & 313.92 & $2.58 \mathrm{E}+02$ \\
\hline 360 & & & 3 & 5.449 & 0 & 17.484 & 4/24/2008 10:05 & 5/7/08 12:00 & 313.92 & $2.46 \mathrm{E}+02$ \\
\hline
\end{tabular}


Table A-2. Desorption Experiment

\begin{tabular}{||c|c|c|c|c|c|c|c|c||}
\hline \hline ID & $\begin{array}{c}\text { ID IN } \\
\text { TABLE } \\
\mathbf{1}\end{array}$ & SOLID & $\begin{array}{c}\text { EXCHANGE } \\
\text { ANION }\end{array}$ & REP & $\begin{array}{c}\mathbf{N O}_{3} \\
(\mathbf{P P M})\end{array}$ & $\begin{array}{c}\mathbf{C O}_{3} \\
(\mathbf{P P M})\end{array}$ & $\begin{array}{c}\mathbf{P O}_{4} \\
\text { (PPM) }\end{array}$ & $\begin{array}{c}\mathbf{1}_{\mathbf{C}} \mathbf{C} \\
\text { (DPM/ML) }\end{array}$ \\
\hline \multicolumn{2}{|c|}{ Instruction step: } & 2 & & 2 & 3 & & \\
\hline $501-\mathrm{N}$ & 309 & Clay & Nitrate & 1 & 6020 & & & $8.84 \mathrm{E}+00$ \\
\hline $502-\mathrm{N}$ & 310 & & & 2 & 5940 & & & $8.84 \mathrm{E}+00$ \\
\hline $503-\mathrm{C}$ & 311 & & Carbonate & 1 & & 1070 & & $1.91 \mathrm{E}+01$ \\
\hline $504-\mathrm{C}$ & 312 & & & 2 & & 1060 & & $2.01 \mathrm{E}+01$ \\
\hline $505-\mathrm{P}$ & 313 & & Phosphate & 1 & & & 10300 & $2.01 \mathrm{E}+01$ \\
\hline $506-\mathrm{P}$ & 314 & & & 2 & & & 12000 & $1.80 \mathrm{E}+01$ \\
\hline $507-\mathrm{N}$ & 337 & Cement & Nitrate & 1 & 6420 & & & $8.85 \mathrm{E}+00$ \\
\hline $508-\mathrm{N}$ & 338 & & & 2 & 6320 & & & $8.86 \mathrm{E}+00$ \\
\hline $509-\mathrm{C}$ & 339 & & Carbonate & 1 & & 1050 & & $1.59 \mathrm{E}+01$ \\
\hline $510-\mathrm{C}$ & 340 & & & 2 & & 1050 & & No Data \\
\hline $511-\mathrm{P}$ & 341 & & Phosphate & 1 & & & 10100 & $2.79 \mathrm{E}+02$ \\
\hline $512-\mathrm{P}$ & 342 & & & 2 & & & 12300 & $9.41 \mathrm{E}+01$ \\
\hline $513-\mathrm{N}$ & none & & nitrate & total & 6530 & & & No Data \\
\hline $514-\mathrm{C}$ & none & & Carbonate & total & & 1160 & & No Data \\
\hline $515-\mathrm{P}$ & none & & Phosphate & total & & & 10500 & No Data \\
\hline
\end{tabular}




\section{DISTRIBUTION}

R. S. Aylward, 773-42A

B. T. Butcher, 773-43A

D. A. Crowley, 773-43A

G. P. Flach, 773-42A

F. L. Fox, 704-59E

J. C. Griffin, 773-A

L. L. Hamm, 773-42A

R. A. Hiergesell, 773-43A

G. K. Humphries, 705-3C

D. I. Kaplan, 773-43A

D. Li, 999-W

J. J. Mayer, II, 773-42A

M. A. Phifer, 773-42A

K. A. Roberts, 773-43A

K. H. Rosenberger, 766-H

R. R. Seitz, 773-43A

D. F. Sink, 704-56E

F. G. Smith, III, 773-42A

G. A. Taylor, 773-43A

M. T. Whiteside, 772-F

C. Wilson (1 file copy \& 1 electronic copy), 773-43A - Rm. 213 